surfactant phospholipids from turhey lung: Comparison with rabbit lung. Amer. J. Physiol.. 218: 218 (1970).

5. Faridy, F, LE Permut, S., and Riley, R. I.: Iffect of ventilation on surface force in excised lungs. J. Appl. Physiol., 21: 1453 (1960).

6. Forest. J. B.: The effect of hyperventilation on the size and shape of alveoli. Brit. J. Anlesthesiol. 42:810(1970).

7. Gribetr, I Fank, N, R and Avery, M L. Static volume-pressure relations of excised lungs of infants with hyaline membrame disease, newborn and stillborn infants. J. Clin. Invest., 38: 2168 (1959)

8. Johnson, R. P., levine, B. I., and Cummings, 1. G.: Alteration of pulmonary surfattant and quasi-static pressure-volume relationships in rat lungs. Fed. Proc.. 23: $150(1964)$.

9. M.Clenahan, J. B., and Urmomski, A.: IEffect of ventiation on surfactant and its turnover ritte. J. Appl. Physiol., 23: $215(1967)$

10. Pattle, R. 1.: Surface lining of lung alveoli. Physiol. Rev., 45: $48(196,5)$.

11. Robertson. B. and Entrinning. G.: The alveolar lining of the premature newborn rabbit after pharyngeal deposition of surfactant. Lab. Invest. 31: $54(1974)$.

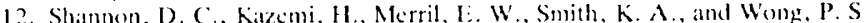
L.: Restoration of volume-pressure curves with lecithin fog. J. Appl. Physiol., 28: $470(1970)$

13. Weibes, E. R.: Postnatal growth of the lung and pulmonary gats-exchange capacity. In: A. V. S. DeReuck, and R. Porter: Development of Lung. (Little Brown, Boston, 1967).

14. These studies were supporled by funds from the United States Public llealth Sorvice and the National cystic Fibrosis Rescarch Foundation.

15. Reguests for reprints should be addressed to: F. H. Adams, M. D. . Division of (ardioleges. Departencent of Pediatrics. University of California. School of Medicine, Center for the Health Sciences, Los Angeles, Califurnia 900)24 (USA).

16. Reccived for publication March 24. 1976.

17. Accepled for publication September 1.1976

\title{
Plasma Aldosterone Concentrations during the Neonatal Period
}

\author{
M. ('. RAUX-I:URIN. ${ }^{\prime \prime \prime}$ M. T. PHAM-HUU-TRUNG, I). MARRE(', ANI) F. (IIRARD)

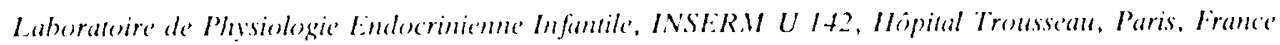

\begin{abstract}
Summary
The direct radioimmunoassay for plasma aldosterone (PA) set up in this laboratory has been reported elsewere. Subjects were 115 normal full term newborns and infants. During the first week of life, there was a wide dispersion in the PA levels $(<1-$ $445, n=89)$, but on the whole these levels were high ( $>6 \mathrm{ng} /$ $100 \mathrm{ml}$ ) and $35 \%$ were higher than those observed in children after stimulation $(>48 \mathrm{ng} / 100 \mathrm{ml})$. Furthermore, there was a negative correlation between $P A$ values and the day of sampling $(P<0.01)$. In older infants, $P A$ values were lower and the ranges narrower. A highly significant negative correlation was found between $\mathrm{Na} K$ ratios and $P A$ levels. The mean geometrical value for PA levels was $53 \mathrm{ng} / 100 \mathrm{ml}$ vs. 1.012 for $\mathrm{Na} K$ mean ratio. When related to weight variations, $P A$ values were randomly distributed. No correlation was found between PA and sodium intakes. The daily urinary excretion of tetrahydroaldosterone and 3-oxoconjugate of aldosterone were lower per se, but when related to surface area, were found to be roughly 3fold those of control adult subjects. We conclude that in the newborn, both the production and excretion of aldosterone are different than values in the adult and that responses to the regulation factors mentioned above are decreased.
\end{abstract}

\section{Speculation}

The direct radioimmunoassay of $P A$ facilitates the evaluation of this hormone during the neonatal period and infancy. The results obtained from plasma and urinary determinations of aldosterone provide evidence for a different pattern of both production and metabolism of aldosterone during these periods. $A_{n}$ appreciation of these $P A$ values and of their regulation is necessary in order to evaluate the significance of $P A$ levels observed in pathologic cases.
It hals previously been reported that PA levels are dramatically clevated during the neonatal period $(3,11)$ and infancy $(5,8)$. However, apart from this common point, the results obtained have been widely dispersed and all authors have found values overlapping those observed in the adult. We undertosk the present study in order to obtain further information on $\mathrm{PA}$ levels, especially during the neonatal period, and to try and relate the results we obtained with a physiologic index of aldosterone activity or regulation.

\section{MII:THODS}

\section{MI:THOI) FOR MIEASURLNHENT OF PA}

The direct radiommunoassay set up in this laboratory has been reported elsewere (11). One milliliter of plasma was extracked with $10 \mathrm{ml}$ methylene chloride and the extract washed first with $1 \mathrm{ml}$ of $0.1 \mathrm{M} \mathrm{Na()H}$ and then with $1 \mathrm{ml}$ distilled water. Different aliquots of the extract. determined according to the expected aldosterone concentrations, were assilyed without further purification with the aid of a highly specific antibody. The sensitivity of the assaly was $1 \mathrm{ng} / \mathrm{log}$ ml plasma. Some plasma samples from newborns were submitted to Sephadex LH20 chromatography as described by Murphy (9), using a methylene chloride-methanol (98:2) solvent.

\section{URINARY MIITABOIITIS OF ALIOSTIRONI:}

These were atsalyed by radioimmunoassaty after column chromatography.

\section{SUBJIECTS}

The subjects were 115 normal full term newborns and infants. Blood samples were tahen from the antecubital vein of the 
resting infants between 9 and 11 AM, i.e., 3-5 hr after the last intake of their ustal food (either mother's milk or commercial milk). Daily weight and total sodium intake were recorded. Five of the newborns were sodium loaded with I $\mathrm{M} \mathrm{NaCl}(3 \mathrm{mEg} / \mathrm{kg} /$ day) in addition to their normal formula.

Urine was collected from series of newborns. In 32 instances, specimens were collected over a period of a few hours with a view 6 determining urinary $\mathrm{Na} K \mathrm{~K}$ ratios. Ten infants were submitted to carefully controlled 24 hr urine collections in order to evaluate the excretion of tetrahydroaldosterone (THA) and of the acid-labile 3-oxoconjugate of aldosterone. Plasma sodium and potassium levels were determined in most cases. In addition, PA was measured in 30 children between the ages of 1 and 14 years and in 33 adult control subjects. Some of the children underwent a synthetic $A C^{\prime}[\mathrm{H}$ stimulation test (Synacthen, 0.25 mg i.m.). Informed consent was obtained from parents of infants and children and, in the case of adult control subjects, from the subjects themselves.

\section{RESULTS}

During the first week of life, there was a wide dispersion in the PA levels (Fig. 1). Four valees ( $4 \%$ ) fell within the range of nonstimulated children $\left(i . e^{\prime},<6 \mathrm{ng} / 10() \mathrm{ml}\right)$, but on the whole, these levels were high and $35 \%$ were even higher than those observed in children after Symathen stimulation (i.e', over 48 $\mathrm{ng} / \mathrm{l}(00 \mathrm{ml}$ ) (Table 1). Furthermore, there was a negative correlation between PA values and the day of sampling. Conversely. the PA values were lower and the ranges narrower in the following age groups: 6 days -3 months and 4-12 months (Table 1). The 1-14-year-old children had PA levels similar to those of adults. All plasmat sodium and potassium levels were within the normal range. Additional studies concerning the values observed in the ()-6-diay-old group were carried out as follows.

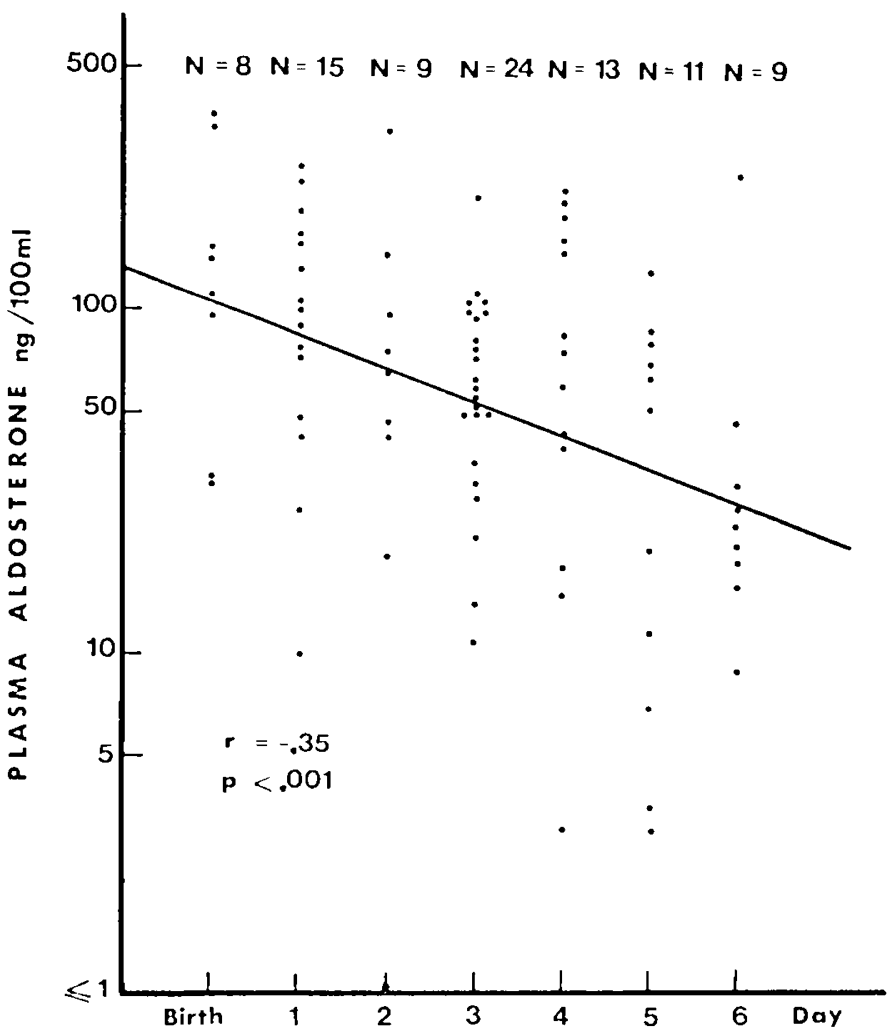

Fig. 1. Plasma aldosterone values in terms of the day of sampling (The regression analysis was undertaken on logarithmically transformed plasma aldosterone values which were taken as the dependent variable.)
Table 1. Plasma aldosterone levels (nanograms per $100 \mathrm{ml}$ ) observed in various age groups

\begin{tabular}{|c|c|c|c|c|c|}
\hline $\mathrm{Agc}$ & $n$ & Range & $\begin{array}{l}\text { Geo- } \\
\text { metricial } \\
\text { mean }\end{array}$ & $\begin{array}{c}95 \% \\
\text { confidence } \\
\text { limit }\end{array}$ & $P$ \\
\hline Birth-6 days & 89 & $<1-445$ & 55.34 & $5.65-542\}$ & $<0.00 \mid$ \\
\hline 7 days -3 months & 19 & $6-128$ & 22.04 & 3.4()$-143\}$, & \\
\hline $4-12$ months & 7 & $3-10$ & 6.06 & $2.81-13.01\}$ & $<0.01$ \\
\hline $1-14$ years & 27 & $<1-6$ & 1.80 & $0.63-5.12$ & $<0.001$ \\
\hline Adults & 33 & $<1-3.8$ & 1.63 & $0.57-4.59$ & $\mathrm{NS}^{\prime}$ \\
\hline $\begin{array}{l}1-14 \text { years (after } \\
\text { short acting } \\
\text { Synacthen } \\
\text { (0.25 mg } \\
\text { i.m.)) }\end{array}$ & 26 & $6-48$ & 14.70 & $3.76-56.7$ & \\
\hline
\end{tabular}

Nonsignificant.

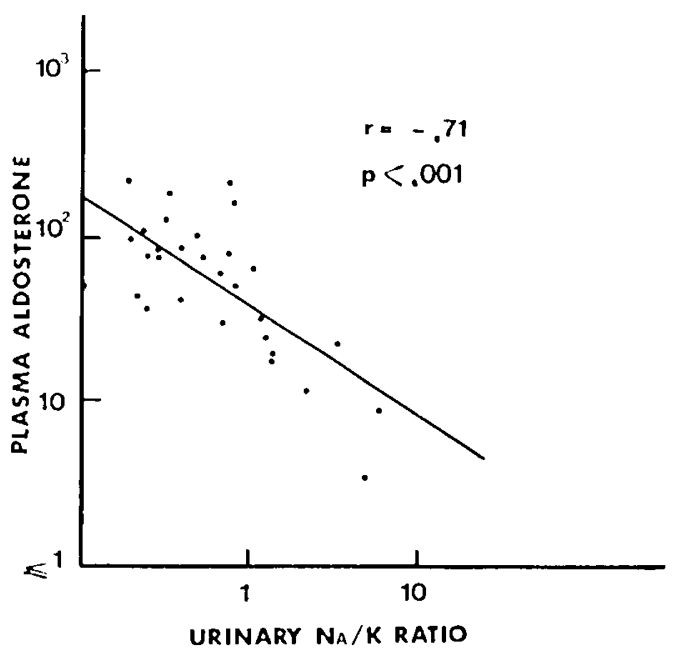

Fig. 2. Correlation between plasma aldosterone levels and urinary $\mathrm{Na} K \mathrm{~K}$ ratio. (Regression analysis was undertaken on logarithmically transformed datia.)

\section{SEPHAIEX LHOU (HRONATOGRAPHY}

Some of the plasma samples with high PA levels were pooled and submitted to Sephadex LH20 chromatography. Only one peak of immunoreactive steroid was obtained and this corresponded perfectly with the elution pattern of tritiated aldosteronc.

\section{URINARY NA:K RATIOS (IIG. 2)}

The 32 infants whose urinary specimens were collected had PA kevels ranging from 3-200 $\mathrm{ng} / \mathrm{l}(00 \mathrm{ml}$. A highly significant negative correlation was found between $N A: K$ ratios and these PA levels. The mean geometrical value for those PA levels was $5.3 \mathrm{ng} / 100 \mathrm{ml}$ vs. 1.012 for NA: K mean ratio.

\section{VARIATIONS IN WEIGHI}

In the first 3-5 days of life the pereentage of weight loss in relation to birth weight was between $3 \%$ and $12 \%$, and this was followed by a normal weight increase. In spite of the progressive decrease in PA levels as the babies grew, these values were randomly distributed when related to weight variations (Fig. 3).

\section{SODIUM INTAKI:}

Sodium intake was evaluated for 20 breast $\mathrm{fed}(<0.3 \mathrm{mE} \mathrm{E} / \mathrm{kg} /$ (lay). $17 \mathrm{bottk}-\mathrm{fed}(0.6-1.3 \mathrm{mEg} / \mathrm{kg} / \mathrm{day})$, and 5 sodium-loaded 


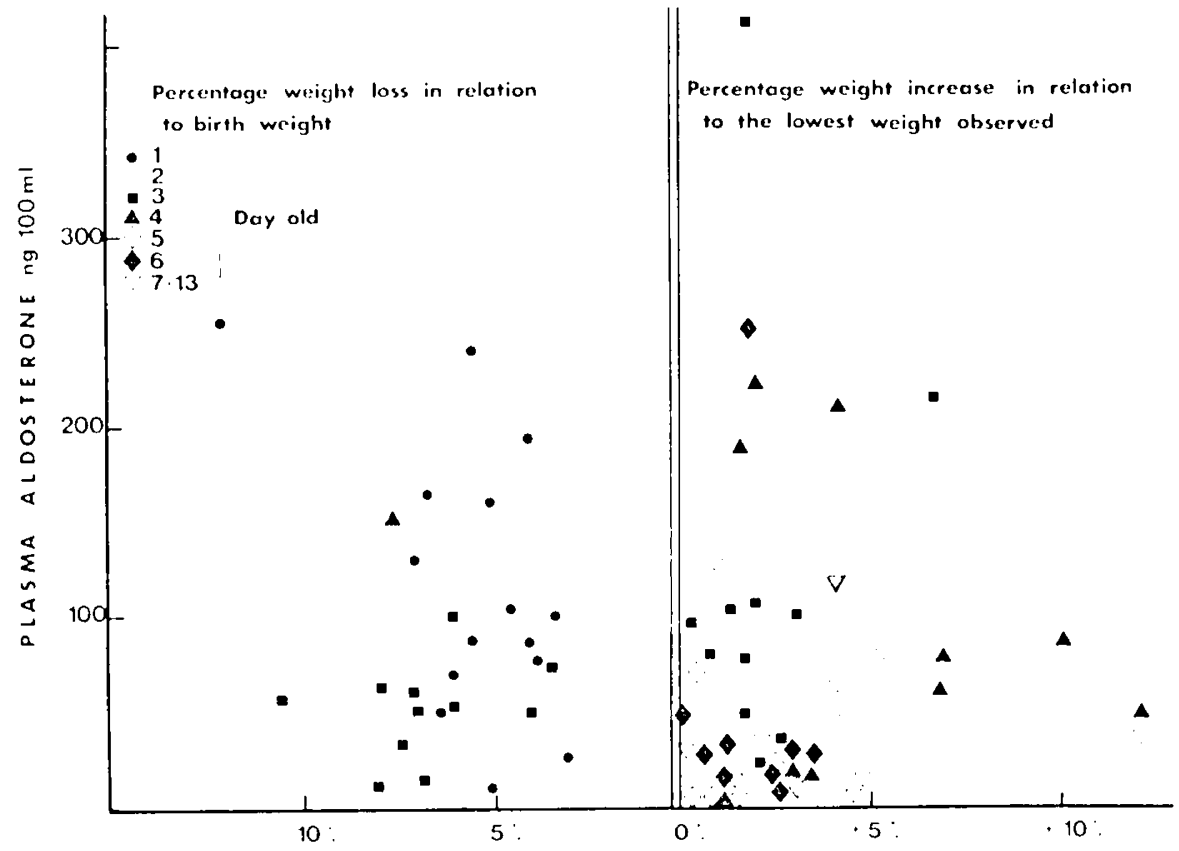

Fig. 3. Daily aldosteronc values as a function of weight variations.

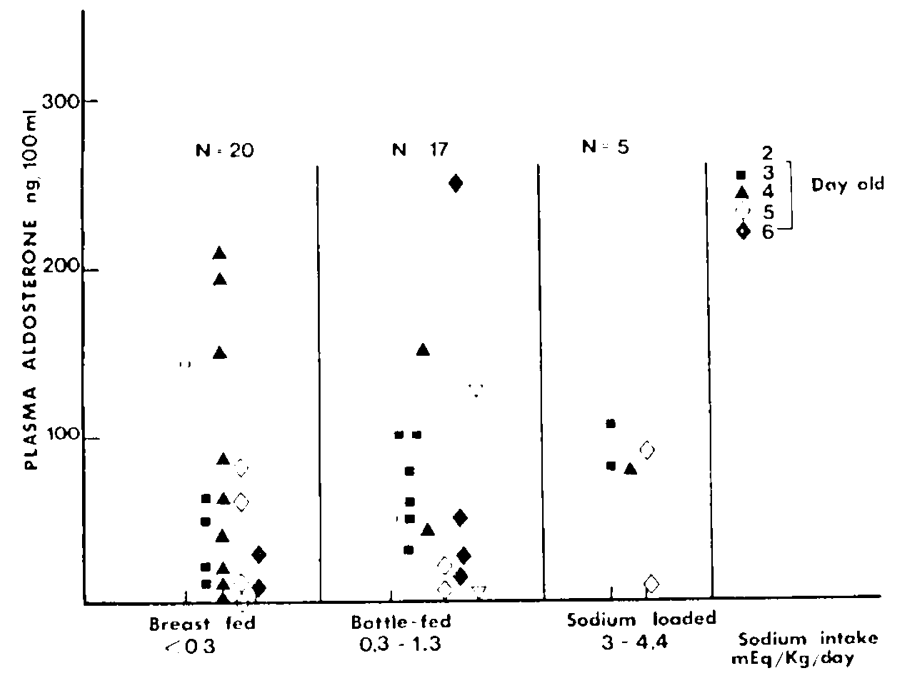

Fig. 4. Daily aldosterone vilues as a function of solium intake.

(3-4.4. mI:y/kg/day) infants aged 2-6 days. No correlation was found between PA and sodium intake (Fig. 4).

\section{MIIASUREMINT OF DAILY URINARY LXCRETHON OF THA AND 3- OXOCONJUCAATI: OI ALDOSTIRONE: (WABLI: 2)}

These values were low, per se, but when related to the surface area, they were found to be roughly 3 -fold those of control adult subjects. A correlation wats found hetween the newborn's urinary excretion of THA and the acid-labile conjugate of aldosterone $(r=0.75)$ with a mean TliA to 3 -oxoconjugate ratio of 2.4 . There was, however. no correlation between these urinary metabolites and either the urinary $\mathrm{Na}: \mathrm{K}$ ratios or the PA levels.

\section{I)ISCUSSION}

Several questions concerning the PA levels observed in the newborn arise. not only from our data, but also from those of other authors.
Table 2. Urinary metabolites of aldosterone"

\begin{tabular}{|c|c|c|c|c|c|c|}
\hline 1:xp. & Age, days & $\begin{array}{c}\text { ТнА, } \mu \mathrm{g} / \\
24 \mathrm{~h}\end{array}$ & $\begin{array}{l}30 \times O \\
\mu \mathrm{g} / 2+\mathrm{hr}\end{array}$ & $\begin{array}{l}\text { THА:3- } \\
\text { OXO }\end{array}$ & $\begin{array}{c}\text { Urinary } \\
\text { Na:K }\end{array}$ & $\begin{array}{l}\text { PA, ng/ } \\
100 \mathrm{ml}\end{array}$ \\
\hline 1 & 1 & 4.5 & 1.5 & 3 & 0.26 & 75 \\
\hline 2 & 1 & 10.9 & 4.4 & 2.5 & ().3.3 & 1.30 \\
\hline 3 & 1 & 1.6 & 0.7 & 2.3 & 0.22 & 4.4 \\
\hline+ & 1 & 11.5 & 3.7 & 3.1 & 0.34 & 60 \\
\hline 5 & 2 & 3.1 & 2.2 & 1.4 & 0.27 & 9.5 \\
\hline 6 & 2 & 0.10 & 4.4 & 2.3 & 1.05 & 4.5 \\
\hline 7 & 3 & 14.8 & 7.1 & 2.1 & 0.2 & 100 \\
\hline 8 & 3 & 3.9 & 1.8 & 2.2 & 0.06 & 98 \\
\hline 9) & 3 & 6.5 & 2.3 & 2.8 & 0.7 & 7.5 \\
\hline \multirow[t]{2}{*}{10} & 3 & 4.5 & 2.5 & 1.8 & 0.86 & 51 \\
\hline & Adults: & $20-50)$ & $6-10$ & & & $<1-3.8$ \\
\hline
\end{tabular}

1 THA: tetrahydroaldesterone; 3-OXO: 3-oxoconjugate; PA: plasma aldesterme.

" Normal sodium intitic.

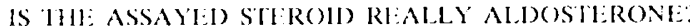

There is a good deal of experimental evidence that the steroid we assayed is indeed aldosterone. The specificity of the direct assay has been previously tested and no cross-reaction was found with the usual circulating steroids (11). Furthermore, the results obtained after chromatography of some of the plasma samples from newborns were in total agreement with those of the direct atssily.

HAVE THISSE S(ATTIEREI) ALDOSTIRONVE IIEVLLS SONII: PHYSIOLOGICAL SIGNIFICANC'T:"

Urinary $\mathrm{Na} K \mathrm{~K}$ ratios are assumed to be a function of the renal tubular response to aldosterone (1.3). We were able to relate urinary Na:K ratios obtained from newborms to their PA levels. However, it should be noted that the urinary $\mathrm{Na} K \mathrm{~K}$ ratios were also widely dispersed and that the lowest Na:K ratios. which should correspond with some state of hyperaldesicronism, were whtand in association with very high PA values (ranging from $3(1-206 \mathrm{ng} / 100 \mathrm{ml})$. These findings might reflect a relative insensitivity of the newbon's kidney to aldosterone. This has been 
previously assumed by Greenberg ot al. (7), who used aldosterone perfusions. Unfortunately, no aldosterone measurements were performed in the course of these studies.

IN VIEW OF THE WIDI DISPERSION, CAN PA VALUES BE RLLATIED TO FACTORS WHCH USUALLY INTERFIRE: WITH ALDOSIIERON! RE:GULATION:

IVe investigated two physiologic events which occur in the newborn. $i$ ee, the variations in weight and the wide range of sodium intake which oceur whether newborns are breast fed or bottle fed.

Neonatal decrease in weight is due to losses of both intracellular and extracellular water. Furthermore, an important decrease of body chlorides in newborns has been described (4). Our data indicated no relationship between these observations and PA levels. $A$ decreatse in urinary excretion of aldesterone at the time of maximum weight loss has been reported (1), but this study was done in premature infants whose sodium and volume regulations are known to be different from those of full term newborns (2). Acute blood volume change in the course of exchange transfusions was not found to induce PA changes in full term newborns (6).

No signifieantly different aldosterone levels were demonstrated in three distinct categories of newborns (breast fed, bottle fed, or sodium loaded), whose sorlium intake covered a range from $0.3-4.5 \mathrm{mEq} / \mathrm{kg} / \mathrm{day}$.

Similar indications were reported by Siegel at al. (12), who found no correlation between the $P A$ levels and the sodium intatic of normal preterm, full term, or small for gestational age infants whose sodium intakes were within the same range as those administered in this study. These authors, however, found a weak correlation in infants with the respiratory distress syndrome who were given parenteral loads of sodium $(2-8 \mathrm{mE} / \mathrm{kg} /$ daty of $\left.\mathrm{NaHIC(} \mathrm{O}_{3}\right)$.

\section{IS THIERE AN ALDOSTLRONE METABOLISM PLCCULIAR TO THE NIEONATAL PERIOD?}

From our data, there is evidence that both the important metabolic pathways of aldosterone are active in newborns and, as previously reported (10), that the ratio of urinary THA to 3oxoconjugate is similar to that in the adult. Furthermore, the urinary excretion of the 3-oxoconjugate of aldosterone has been shown to correlate perfectly with the aldosterone secretion rate in infants (14). The triated aldosterone excreted in urine as 3oxoconjugate was found to be $6-15 \%$ of the administered dose (14). Therefore, the excretion of aldosterone metabolites appears to be low in even those newborns whose PA levels were $30-80$-fold those of adults. In the absence of available data concerning accurate measurements of the metabolic clearance rate of aldosterone in newborns, this maly be considered an indirect argument for a slower rate of metabolism of aldosterone during this period.

\section{CONCLUSION}

During the first weet of life. PA levels are generally very high but values are widely dispersed. A relative insensitivity of the renal tubule may be involved since low urinary $\mathrm{Na} K \mathrm{~K}$ ratios are accompanied by considerably clevated PA levels. A decrease in the metabolic clearance rate is also possible. We conclude that, in the newborn. both the production and excretion of aldosterone are quantitatively different from those in the adult, and that responses to regulatory factors mentioned above, $i . e^{\prime}$, variations in volume or sodium intake, are decreased.

\section{REFERINCES AND NOTIS}

1. Al-Algha, S. K., Collipp, P. J., and Klein, S. W.: Neomatal weight loss and aldesterone excretion. JAMIA, 2l0: $1763(1969)$.

2. Aperia. A., Borberger, O., Thodenius, K., and Zetterstrom, R.: Develop mental study of the renal response to an oral salt load in preterm infants. Acta Palediat. Scand., 63: 517 (1974).

3. Beitins, I. Z., Bayyard, F. Levitsky, L., Ances, I. G.. Kowarski, A. and Migcon, C. J.: Plasma aldesterone concentration at delivery and during the newborn period. J. Clin. Invest. 51: 386 (1972).

4. Check, D. B.. Maddison. T. G., Milinek, M., and Coldheck, J. H.: Further observations on the corrected bromide space of the neonate and investigation of water and electrolyte status in infants born of diabetic mothers. Pediatrics, 28: 861 (1961).

5. Dillon, M. J.. and Ryness, J. M.: Plasma renin activity and aldosterone concentration in children. Brit. Med. J., 4: 316 (1975)

6. Dillon, M. J., Milner, R. D. G., Rajani, K. B., and Ryness, J.: Effects of acute blood volume change on plasma renin and aldosterone in the newborn. Pediat. Res., 9: 861 (1975).

7. Greenberg. A. J., MeNamara H., and MeCrory. W. W.: Renal tu'bular response to aldosterone in normal infants and children with adrenal disorders. J. Clin. Endecrinol., 27: $1197(1967)$.

8. Kowarski, A., Katz. H., and Migeon, C. J.: Plasma aldesterone concentration in normal subjects from infancy to adulthood. J. Clin. Endocrinol., 38: 489 (1974).

9. Murphy. B. E.: "Sophadex" column chromatography as an adjunct to competitive protein binding assalys of steroids. Nature New Biol., 232: 21 (1971).

10. New, M. I., Miller, B.. and Peterson, R. F.. Aldosterune excretion in normal children and in children with adrenal hyperplasia. J. Clin. Invest.,45:412 $(1966)$.

11. Pham-1luu-Trung. M. T.. and Corvol P.: A direct determination of plasma aldosterone. Steroids, 24: 587 (1974).

12. Siegel, S. R., Fisher, D. A., and Oh, W.: Serum aldosterone concentrations related to sodium balince in the newborn infant. Pediatries. 53: 410)(1974).

13. Sonnenblick. E. H., Cannon P. J., and Laragh, J.: The nature of the action of intravenous aldosterone: Evidence for a role of the hormone in urinary dilution. J. Clin. Invest., 40: 903 (1961).

14. Weldon, V. V.. Kowarski, A., and Migeon, C. J.: Aldosterone secretion rates in normal subjects from infancy to adulthood. Pediatrics, 39: 713 (1967).

15. We wish to thank Drs. H. Brissaud. J. Herve, R. Laplane, and J. Salat Barout who referred newborns and infants to us. We are very grateful to Doctor legrand for the determinations of urinary metabolites of aldosterone.

16. Part of this work was presented at the Seventh Mecting of the International Study Group for Steroid Hormones. Rome, December, 1975.

17. This study wats supported by INSERM.

18. Requests for reprints should be addressed to: M. C. Raux-Lurin, M.D., Hopital Trousseau, 26. Av. du Docteur Arnold Netter, 75012 Paris (France).

19. Received for publication March 29.1976.

20. Accepted for publication September 1, 1976. 